\title{
Modelling Genetic Susceptibility to Multiple Sclerosis with Family Data
}

\author{
Cullen O'Gorman ${ }^{a}$ Rui Lin ${ }^{b}$ James Stankovich ${ }^{b}$ Simon A. Broadley ${ }^{a, c}$ \\ ${ }^{a}$ School of Medicine, Gold Coast Campus, Griffith University, Gold Coast, Qld., b Menzies Research Institute Tasmania, \\ University of Tasmania, Hobart, Tas., and ' Department of Neurology, Gold Coast Hospital, Southport, Qld., Australia
}

\section{Key Words}

Familial risk - Genetics • Multiple sclerosis • Relative risk • Recurrence risk

\begin{abstract}
A genetic contribution to susceptibility is well established in multiple sclerosis (MS) and 57 associated genetic loci have been identified. We have undertaken a meta-analysis of familial risk studies with the aims of providing definitive figures for risks to relatives, performing a segregation analysis and estimating the proportion of the overall genetic risk that currently identified genes represent. We have used standard methods of meta-analysis combined with novel approaches to age adjustment to provide directly comparable estimates of lifetime risk. The overall recurrence risk for monozygotic twins was $18.2 \%$ and for siblings $2.7 \%$. The recurrence risk for dizygotic twins was significantly higher than for siblings. The overall estimate of sibling relative risk $\left(\lambda_{S}\right)$ was 16.8 . Risks for older relatives (parents, siblings, aunts, uncles and cousins) show a latitudinal gradient, in line with population risk. No latitudinal gradient for $\lambda_{S}$ was seen. Segregation analysis supports a multiplicative model of one locus of moderate effect with many loci of small effect. The estimated contribution of the 57 known MS loci is $18-24 \%$ of $\lambda_{S}$. This meta-analysis supports the notion of MS being in part the result of multiple genetic susceptibility factors and environmental factors.
\end{abstract}

Copyright $\odot 2012$ S. Karger AG, Basel

\section{KARGER}

Fax +4161306 1234

E-Mail karger@karger.ch

www.karger.com
(C) 2012 S. Karger AG, Basel

0251-5350/13/0401-0001\$38.00/0

Accessible online at:

www.karger.com/ned

\section{Introduction}

Multiple sclerosis (MS) is a frequently disabling disease of the central nervous system [1]. There is good evidence for complexity in the aetiology of MS, with both environmental and genetic influences on susceptibility. Smoking [2], Epstein-Barr virus [3] and relative vitamin $\mathrm{D}$ deficiency $[4,5]$ have all been associated with increased susceptibility to MS. Cross-sectional studies of MS patients and their families [6] together with twin studies [7] have pointed to a genetic contribution to the MS risk. These data have been further supported by studies of adoptive relatives [8], half-siblings [9] and offspring of conjugal pairs [10]. Definite association with the major histocompatibility complex (MHC) was described in the 1970s [11]. Linkage to HLA was confirmed through genomewide linkage studies in affected relative pairs [12]. Additional MHC and non-MHC loci have been identified through genomewide association studies and meta-analyses [13-16].

Despite these advances in genetic analysis, we still have an incomplete picture of the overall genetic architecture of MS susceptibility, as the identified associations only explain a small fraction of the familial aggregation of MS. Accurate estimates of family risk are required to estimate the scale of this fraction. Data from family studies in conjunction with known genetic associations and allele frequencies can be used to measure the strength of 
genetic contribution to MS risk and estimate the total number of genes involved. Accurate estimates of family risk can guide gene-finding studies and help interpret the significance of candidate genes identified [17].

Whilst a number of large recurrence risk studies have been conducted in MS, there has been a large variation in estimated values for sibling relative risk $\left(\lambda_{S}\right)$, a widely used measure of genetic contribution to susceptibility. Estimates of risk to more distant relatives have been more problematic due to the low frequency of recurrence and variability in the estimation of population prevalence.

With the aims of more accurately defining estimates of recurrence risk for each class of relative and determining the possible patterns of inheritance of susceptibility alleles [18], we have undertaken a systematic meta-analysis of published recurrence risk data. We have used these data to calculate relative risks for each class of relative $\left(\lambda_{R}\right)$ [19]. We have gone on to use these data in a segregation analysis to establish the most likely underlying genetic model for MS and examine the potential influence of environmental factors. We have also used these data to estimate the heritability of MS and the extent to which the currently defined associated loci might explain this heritability.

\section{Methods}

Identification of Family and Twin Studies

Articles were located through a search of PubMed (1964 to present), the Cochrane library, CINAHL (Cumulative Index to Nursing and Allied Health Literature) and Google scholar, using the term 'multiple sclerosis' in combination with the following, limited to title and abstract: 'family study', 'inheritance', 'recurrence risk', 'sibling', 'conjugal', 'consanguineous', 'half-sibling', 'half-sib', 'half-sibs', 'avuncular', 'adopted', 'adoptee', 'twin' and 'twins'. References were checked to identify other eligible studies. Foreign language articles were included if their abstract was in English. Studies were included if they were a systematic collection of affected and unaffected relatives in families of MS probands. Studies were required to have defined MS cases using standard criteria of the time [20-23]. All studies used proband identification of suspected cases within families either face to face or by postal questionnaire. Affected cases were confirmed through clinical examination where possible or by reference to a national register (if available), examination of medical records and death certificates, or where no records could be traced, the related history of the clinical condition and judgement of the investigator, with only classical histories being accepted.

Studies were excluded if insufficient data were provided to recalculate crude risks to relatives, or if only a single pedigree was described. Where a population had been studied repeatedly, the most recent data were used. For twin studies, additional exclusion criteria were: if zygosity had not been determined by a valid clinical or genetic method [24,25], and if only one monozygotic (MZ) or one dizygotic (DZ) twin pair was described.

\section{Determination of Population Lifetime Risk}

Contemporaneous and geographically relevant prevalence studies using the Schoenberg-Kurtzke definition [26] were identified for each family or twin study. Lifetime prevalence data from the original study were utilised when these were provided or were calculated using a novel variation of the modified Strömgren method [27] (see below) using temporal and region-specific ageof-onset and census data. Where age-of-onset data for a population were unavailable, an average of all available datasets was used.

Conventional weighting in meta-analysis would reflect the size of the prevalence study used in addition to the size of the family study. Given the much greater size of population prevalence studies, age-adjusted data for population frequencies of MS were entered as cases per 100,000 to ensure that the $95 \%$ confidence interval (CI) estimates for $\lambda$ reflect the relative precision of the family study and were not overly influenced by the population data.

\section{Determination of Age-Adjusted Risks for Relatives}

Where quoted, age-adjusted risks (AAR) for relatives have been used. To include data from relatives where this had not been provided, an estimated AAR was calculated using a variation of the prior age-of-onset approach and modified Strömgren method [28]. In the original method, relatives are stratified by age, and the number in each stratum is adjusted with reference to the age-ofonset distribution of MS for the population. Lifetime recurrence risks are estimated by dividing the number of affected relatives (numerator) by the adjusted number of at-risk relatives (the adjusted denominator). A modifier was derived for the overall age adjustment for each relative group based on studies where age adjustment had been performed. A weighted average of this modifier was used to derive AAR where these data were lacking. In the case of data for Queensland and Tasmania where age adjustment had not been performed in more distant relatives, we used a further modification of this method based on the estimated mean age of these relatives and local age-of-onset data.

In order to ensure consistency between studies, we used Grubbs' [29] test to look for outliers in age-adjusted modifiers. Statistically significant outliers $(\mathrm{p}<0.05)$ were rejected and crude risks were age adjusted according to the procedure outlined above. As a check of ascertainment for more distant relatives, we have used a novel comparison of observed fertility rates between aunts/uncles and parents. Because parents are selected on the basis of their affected offspring being identified as a case, it is necessary to correct for the estimated cohort lifetime fertility rate in the population (taken as the proportion of women above the age of 45 years who have had at least one child). Ratios of fertility rates (mean number of offspring) in aunts/uncles versus parents were compared with the expected value of 1.0 using $95 \%$ CI based on adjusted offspring number (numerator) rather than adjusted parent number (denominator) to provide conservative estimates.

\section{Determination of Risks for Twins}

Pairwise and probandwise risks to twins were calculated. Probandwise concordance rates represent the probability that a twin in a pair is affected given that his/her co-twin is affected [30]. This probability is estimated by the proportion of all probands that belong to concordant pairs and is directly comparable to the recurrence risk for relatives calculated in family studies. All probands are assumed to be singly ascertained, unless the study spe- 
cifically stated otherwise, or gave a probandwise risk derived from doubly ascertained cases. For probandwise concordance risks, 95\% CI were calculated [31].

The mean age of twins in each study was compared to available age-of-onset data for the relevant country and an appropriate modifier calculated to give an age-adjusted pairwise risk. For probandwise risks, the modifier was applied to singly and doubly ascertained pairs separately.

\section{Determination of $\lambda$}

The relative risk $(\lambda)$ to any class of relative can be estimated as: risk to relative divided by population risk [19]. For this analysis, AAR were compared to lifetime population prevalence to calculate relative risks for each class of relative in each study. The resulting values were combined in a meta-analysis using Review Manager [32] on the log scale. Mantel-Haenszel weighting was used to obtain random-effect estimates for $\lambda$. Heterogeneity between studies was assessed with calculation of $\tau^{2}$ and $\mathrm{I}^{2}$ [33], and the construction of funnel plots of $\lambda$ against standard error, generating plots most useful to assess possible bias in studies of similar size [34].

Formulas developed by Risch [18] were used to calculate expected relative risks for various classes of relatives under various models of the genetic architecture of MS. To estimate the total proportion of $\lambda_{S}$ that can be explained by confirmed MS susceptibility loci $i$, the formula to calculate locus-specific sibling relative risks $\lambda_{S i}$ was used, which makes an assumption of multiplicativity [35]. Then, the proportion of $\lambda_{S}$ explained by these confirmed loci is $\left[\Sigma \log \left(\lambda_{S i}\right)\right] / \log \left(\lambda_{S}\right)$. Relative risks were estimated from the large IMSGC/WTCCC2 genomewide association study [16], and allele frequencies were taken from one of the largest control populations in this study, the 1958 UK Birth Cohort [16].

\section{Determination of Heritability}

We have utilised standard estimates of broad sense heritability [36] with modifications for estimates of the regression coefficient of liability [30], which allow for estimation of confidence limits [30].

\section{Determination of Latitude}

Latitudes for individual studies were based on the geographical centre for the region studied using the SEDAC (Socioeconomic Data and Applications Centre) website [37]. In the case of Canada, because of the marked unevenness of population distribution, the estimated population centre was used [38]. Where individual cities were surveyed, the latitude was taken as the geographical centre of the city or an average where multiple centres were surveyed. To assess for interaction between recurrence risk and latitude, we have used linear regression analysis with each study weighted by the inverse of the variance of the recurrence risk estimate for that study. Studies with either 0 cases or $<30$ total relatives were excluded.

\section{Results}

\section{Data Collection}

Initial literature search located over 500 studies. Application of exclusion criteria resulted in 18 eligible family and twin studies (online suppl. tables 1 and 2; for all online supplementary material, see www. karger.com/doi/10.1159/000341902) [39-57].

\section{Age-Adjusted Risks}

Generational analysis of modifiers derived from studies that supplied AAR revealed outliers in three classes of relatives (offspring, aunts/uncles and cousins) for one study (online suppl. table 3) [50] and these were therefore recalculated.

\section{Risks to Relatives}

The pairwise risks for $\mathrm{MZ}$ and $\mathrm{DZ}$ twin pairs for all included studies are summarised in table 1 (see also online suppl. table 4). The overall female:male ratio for index cases amongst same-sex twin pairs, where these data were available, was $2.6: 1$, which is consistent with contemporaneous estimates of gender distribution of MS in the general population [58]. The DZ/MZ ratio was 1.75 for all pairs and 0.95 for same-sex pairs, indicating that MZ pairs accounted for the expected one third of twin pairs $[59,60]$. The mean age of twins (where these data were provided) was 50 years indicating that most subjects studied were likely to have been born prior to the introduction of in vitro fertilisation in the 1970s, which has seen a dramatic increase in the frequency of DZ twins [61].

The age-adjusted probandwise risks for twins and comparable AAR for all relative types are given in table 2 (see also online suppl. table 5). The expected drop-off in risk with lessening degrees of relatedness is observed. As has been noted previously, the risk for parents and offspring is lower than the risk for siblings. In this analysis, the difference between sibling and parent risks was significant. Figure 1 combines the present results with previously published data for risks in less common relative pairs [adoptees [8], half-siblings [9, 62], step-siblings [63], affected sibling and one affected parent (parent-child) $[64,65]$ and two affected parents (conjugal pairs) $[10,66$, 67]; see also online suppl. table 6]. The recurrence risk for offspring of affected conjugal pairs is identical to that for MZ twins, albeit with wide CI, which is to be expected under a multi-factorial threshold model.

The meta-analysis estimates of $\lambda$ for all family relatives from studies meeting the inclusion criteria are shown in figure 2 . The level of heterogeneity $\left(\tau^{2}\right)$ exceeded the 0.1 threshold in most relative types [68], and therefore random-effect models were applied. Funnel plots for each type of relative did not show any evidence of publication bias (online suppl. fig. 1). 


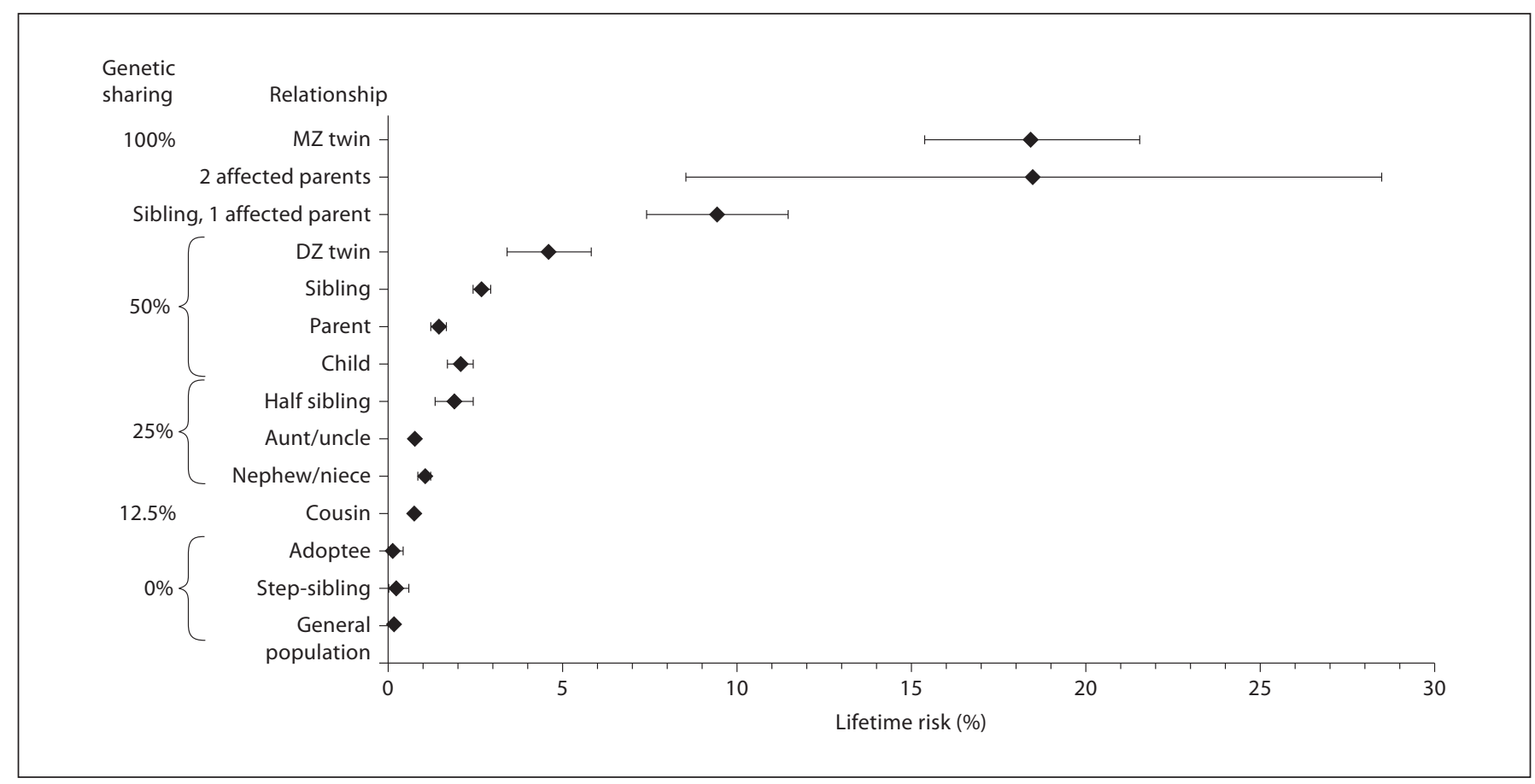

Fig. 1. Chart of lifetime risk (AAR) for various types of relative compared with a weighted mean population lifetime risk. Degree of genetic sharing indicated for each type of relative.

Table 1. Pairwise risks to twins

\begin{tabular}{llcll}
\hline Relative & $\begin{array}{l}\text { Pairwise } \\
\text { risk, \% }\end{array}$ & $95 \%$ CI & AAR, \% $95 \%$ CI \\
\hline MZ twin & 14.3 & $11.7-16.8$ & 15.4 & $12.6-18.1$ \\
$\quad$ Female & 16.3 & $12.9-19.6$ & & \\
$\quad$ Male & 8.9 & $4.4-13.3$ & & \\
DZ twin & 3.7 & $2.7-4.7$ & 3.9 & $2.9-5.0$ \\
$\quad$ Female & 4.7 & $2.7-6.8$ & & \\
Male & 4.1 & $1.1-7.2$ & & \\
Same sex & 4.6 & $3.0-6.3$ & & \\
Opposite sex & 3.2 & $1.7-4.7$ & & \\
\hline
\end{tabular}

\section{Segregation Analysis}

The resulting combined $\lambda$ values for all relatives are given in table 3 . The pooled estimate for $\lambda_{S}$ was $16.8(95 \%$ CI 14.0-20.3). The estimates for $\lambda$ in twins, both MZ and $\mathrm{DZ}$, were lower than those that have been previously generally quoted, but the risk for DZ twins (29.6) remains approximately 4 times lower than for MZ twins (116.5) and is close to the sibling risk, with CI that overlap. The
Table 2. Crude risks and AAR to family members

\begin{tabular}{|c|c|c|c|c|c|}
\hline Relative & Affected & Total & $\begin{array}{l}\text { Crude } \\
\text { risk, \% }\end{array}$ & AAR, \% & $95 \% \mathrm{CI}$ \\
\hline MZ twin ${ }^{1}$ & 129 & 748 & 17.25 & 18.44 & $15.35-21.53$ \\
\hline DZ twin ${ }^{1}$ & 58 & 1,326 & 4.37 & 4.61 & $3.38-5.85$ \\
\hline Sibling & 349 & 16,007 & 2.18 & 2.68 & $2.40-2.95$ \\
\hline Parent & 162 & 11,402 & 1.42 & 1.45 & $1.23-1.67$ \\
\hline Offspring & 37 & 5,860 & 0.63 & 2.07 & $1.41-2.73$ \\
\hline Niece/nephew & 45 & 13,977 & 0.32 & 1.02 & $0.72-1.32$ \\
\hline Aunt/uncle & 124 & 16,944 & 0.73 & 0.75 & $0.62-0.88$ \\
\hline Cousin & 191 & 32,072 & 0.60 & 0.73 & $0.62-0.83$ \\
\hline
\end{tabular}

${ }^{1}$ Affected and total twins are composite totals required to calculate probandwise risks.

other striking feature is that $\lambda$ for cousins is only slightly lower than the combined figure for the risk in seconddegree relatives. In three studies, the ratio of mean family size for aunts/uncles versus parents was significantly below the expected value of 1.0, which suggests significant underreporting of total cousin numbers in these studies (online suppl. table 7). 


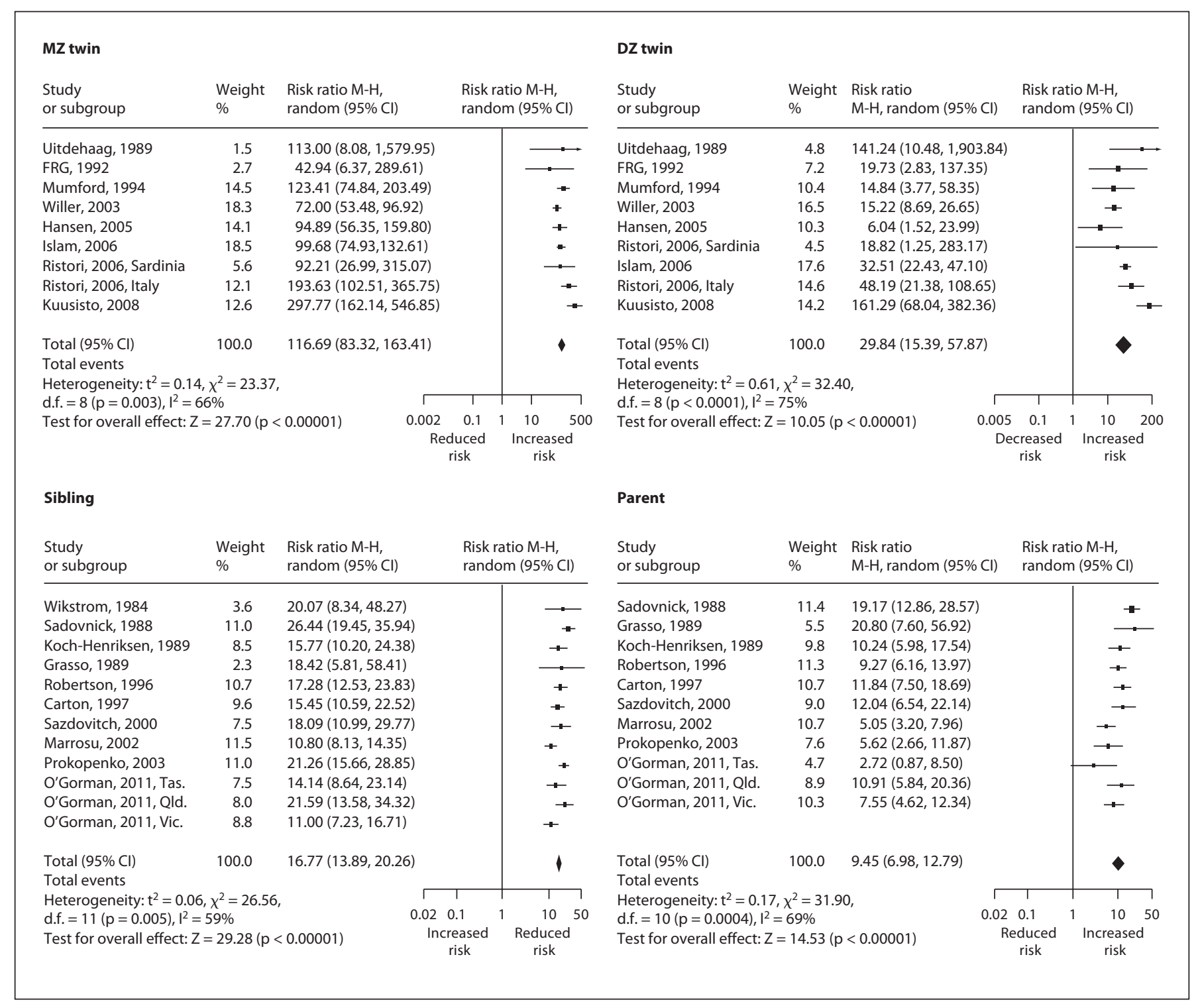

Fig. 2. Forest plots (random-effect models) for estimated $\lambda$ for each type of relative, plotted on log scale. M-H = Mantel-Haenszel weighting.

Table 3 also shows a comparison of the observed data with 10 different models of heritability in a segregation analysis, with each model constrained to match the observed $\lambda_{s}$. It is evident that a recessive single locus model can be discounted on account of the low MZ twin risk. Of all the models tested, the model with one locus of moderate effect $\left(\lambda \_10=4.0\right)$ plus an infinite number of small loci is the closest fit (model V). However, other models of one or several loci of low-to-modest effect also fit well. When the three studies with evidence of underreporting of total cousin numbers are removed from the analysis, the age-adjusted recurrence risk in cousins falls to $0.58 \%$ (95\% CI $0.48-0.69 \%)$ and $\lambda_{3}$ is lowered to 3.90 (95\% CI $3.10-4.91)$. However, $95 \% \mathrm{CI}$ for this amended $\lambda$ remain above the predicted $\lambda$ values for any of the likely genetic models.

\section{Environmental Effects}

We have explored the effect of latitude on the recurrence risk. Figure 3 shows plots of AAR against latitude for 
Offspring

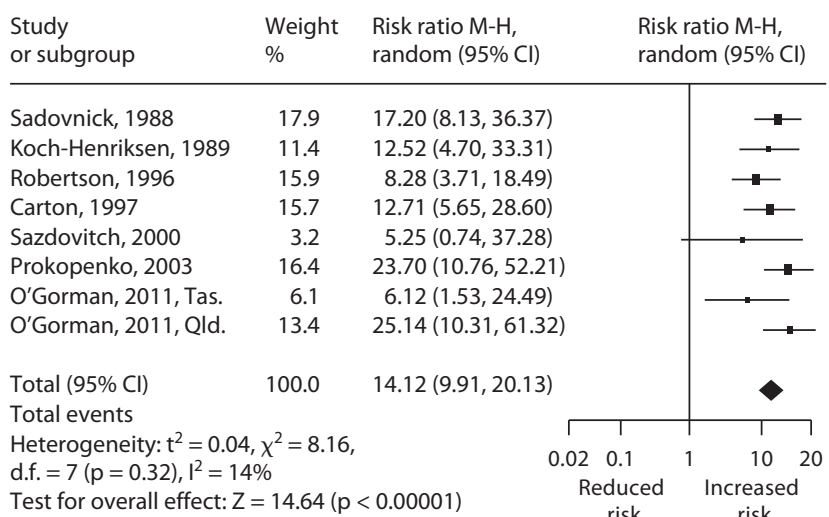

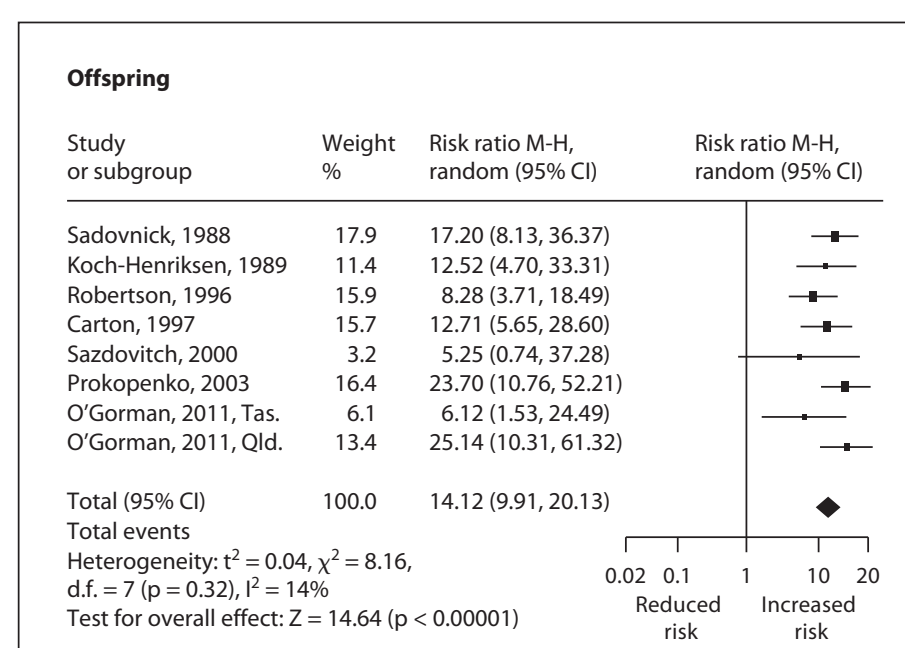

Niece/nephew

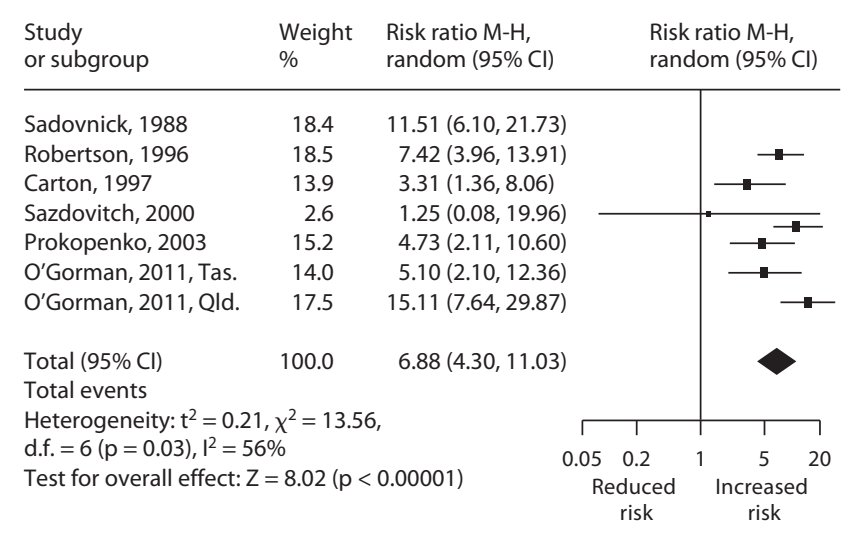

\section{Aunt/uncle}

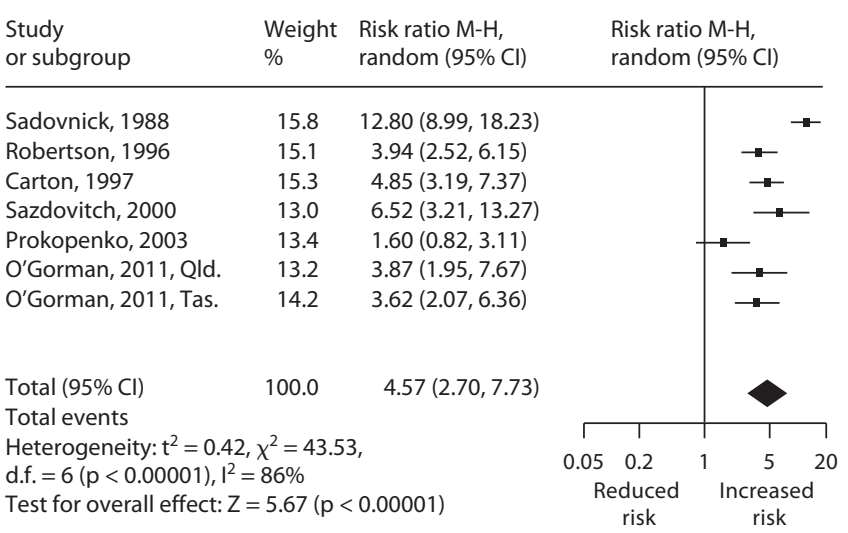

Cousin

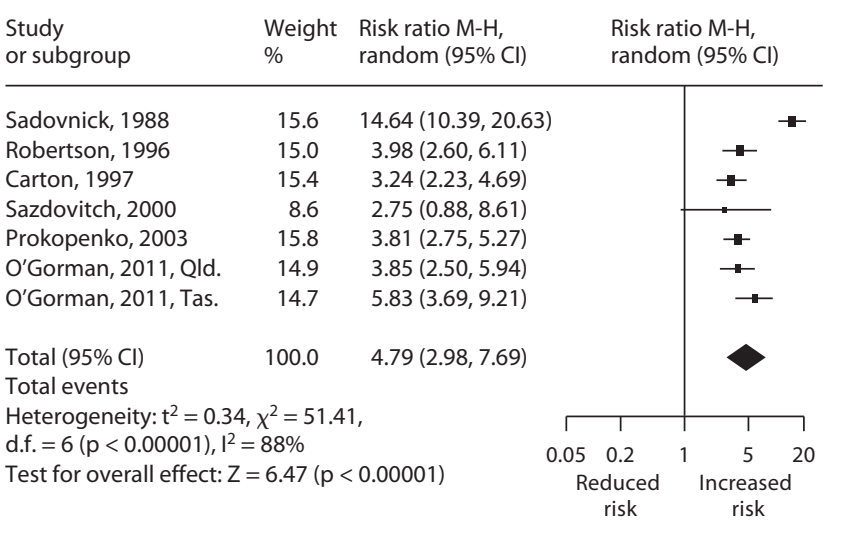

Fig. 2. Forest plots (random-effect models) for estimated $\lambda$ for each type of relative, plotted on log scale. M-H = Mantel-Haenszel weighting.

each relative group. These data show a consistent trend to an increasing risk with increasing latitude except in offspring and nieces/nephews. These data are similar to a previous study comparing recurrence risks in twins against latitude [44]. The trend seems to be greatest for parents and aunts/uncles with a reversal of the slope for offspring and nieces/nephews, hinting that this may reflect an age-dependent effect. However, it should be noted that only the regression coefficient for recurrence risk in parents against latitude was statistically significant $(\mathrm{p}=0.048)$.

When values for $\lambda$ are plotted against latitude, no trend is observed indicating that the risks within families rise proportionally with the population risk as latitude increases (fig. 4; online suppl. table 8).

\section{Heritability}

In order to estimate the overall contributions of genes and environment, we have estimated the broad sense heritability based upon the recurrence risks for $\mathrm{MZ}$ and $\mathrm{DZ}$ twins. This gives values for genetic heritability $\left(h^{2}\right)$ of $54 \%$, shared familial environment $\left(c^{2}\right)$ of $17 \%$ and environment $\left(e^{2}\right)$ of $29 \%$. We estimate that $18 \%$ of the known heritability can be explained by the known loci (including $11 \%$ explained by $\left.H L A-D R B 1^{*} 15: 01\right)$. Assuming that the $54 \%$ genetic heritability and $17 \%$ shared environmental 'heritability' are the same for siblings as for twins gives an upward adjustment [divide by $54 /(54+17)$ ] to the estimate of the genetic contribution of the known MS loci to a maximum of $24 \%$. 
MZ twin

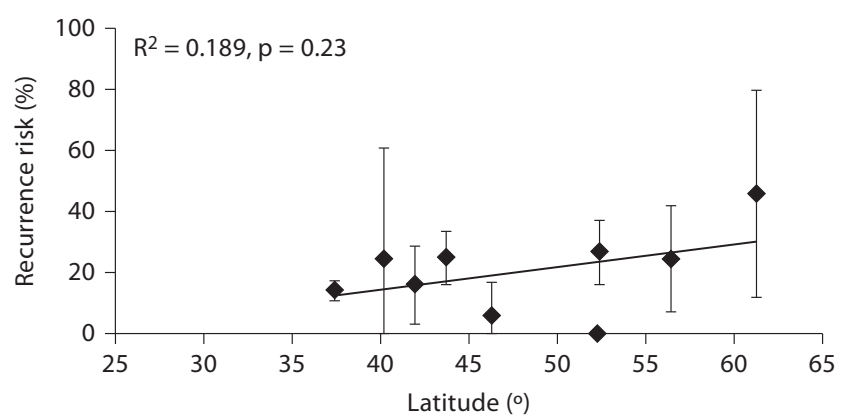

Parent

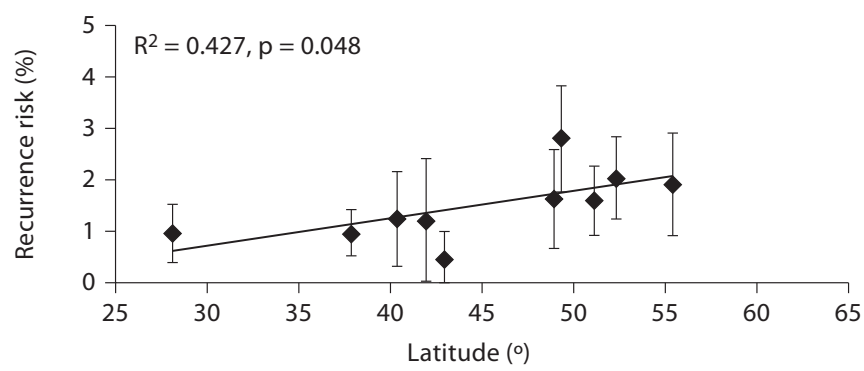

Sibling

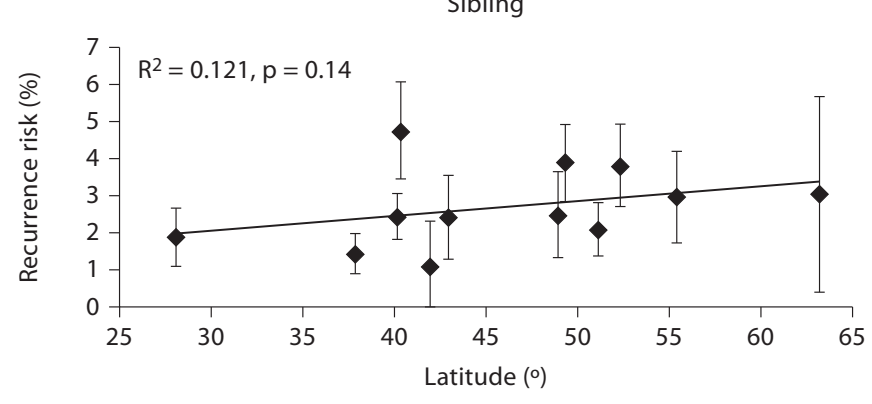

Offspring

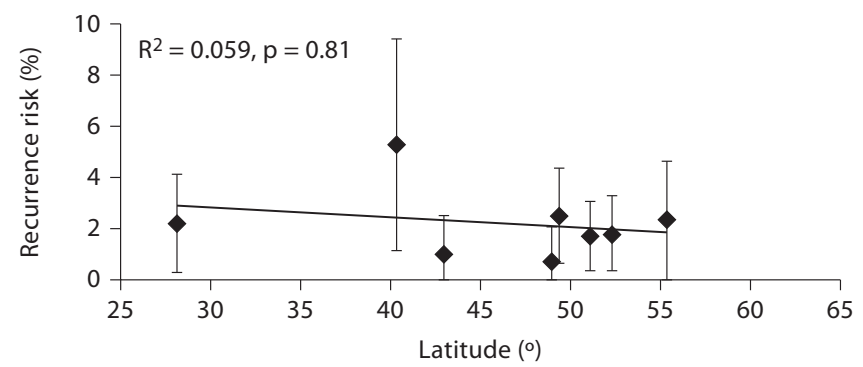

DZ twin

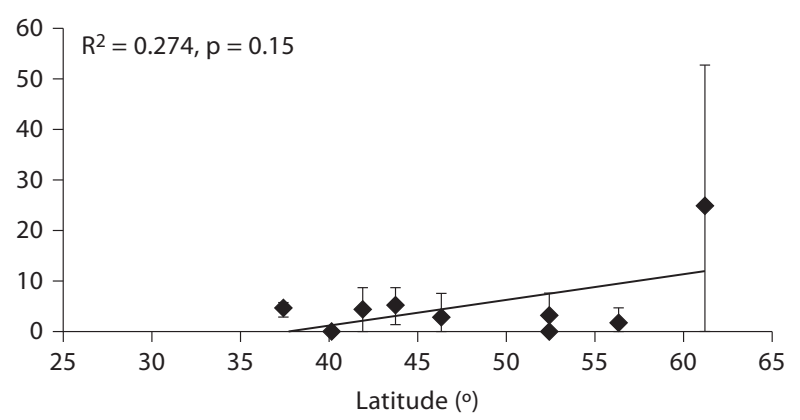

Aunt/uncle

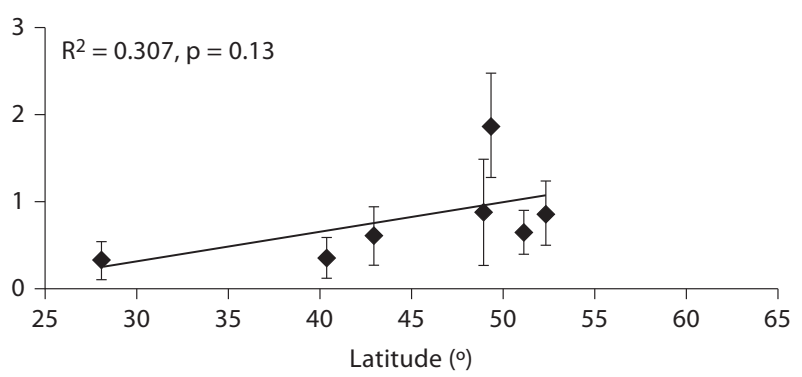

Cousin

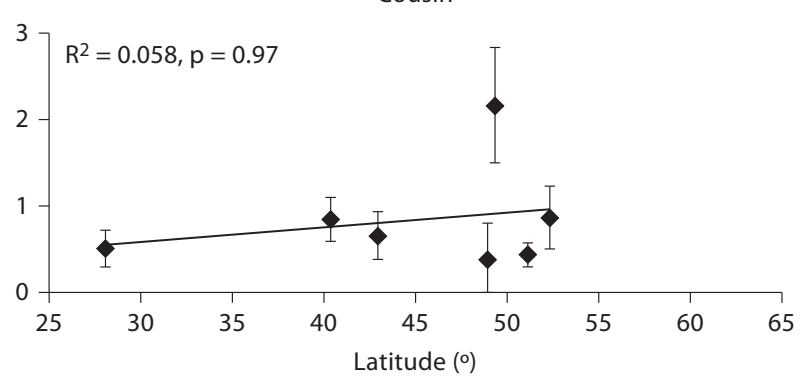

Niece/nephew

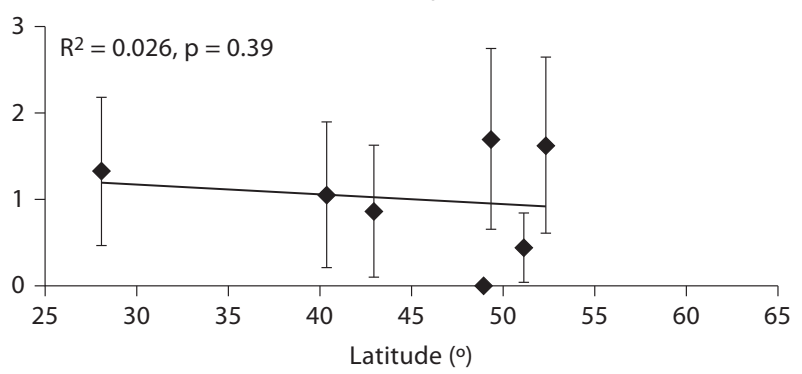

Fig. 3. Plots of recurrence risk against latitude for each type of relative. Trend lines determined by least-squares method. 
Fig. 4. Plot of $\lambda$ against latitude for sibling data.

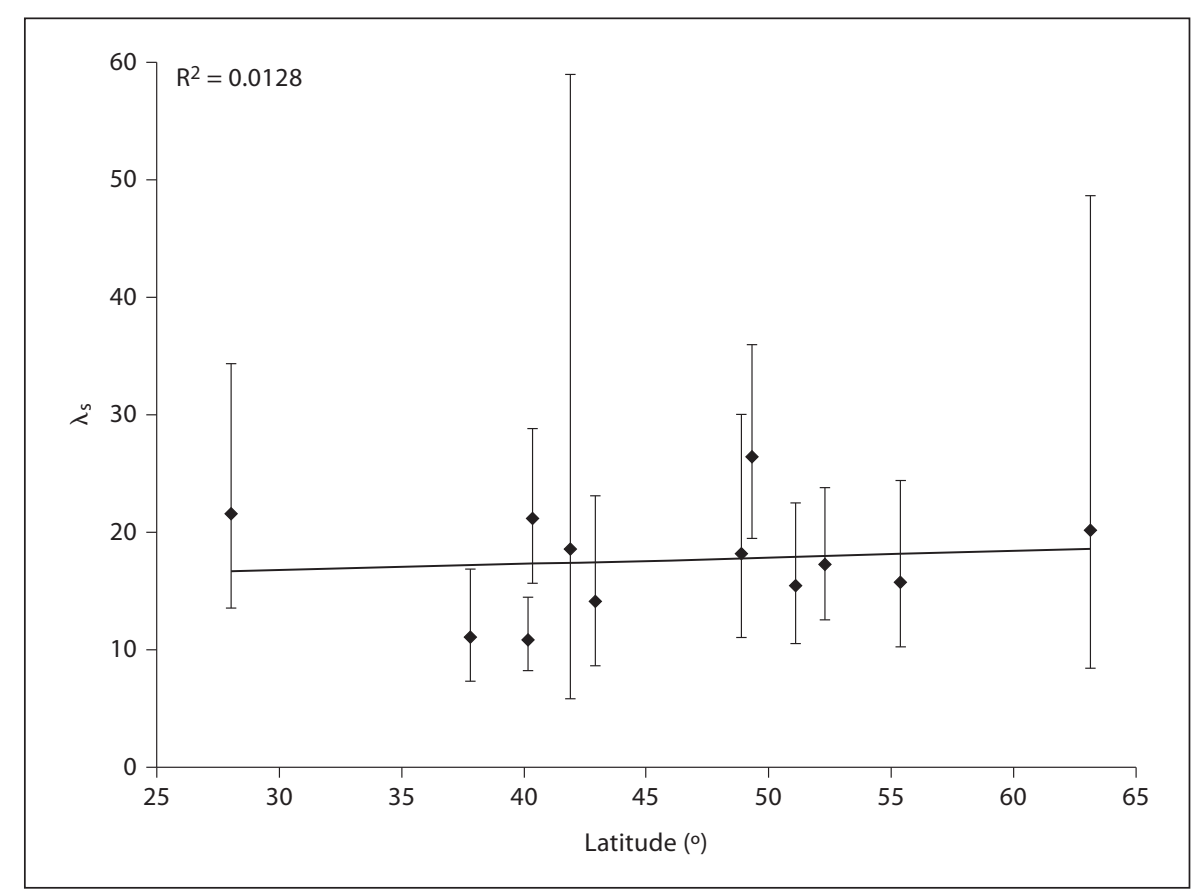

Table 3. Segregation analysis of MS

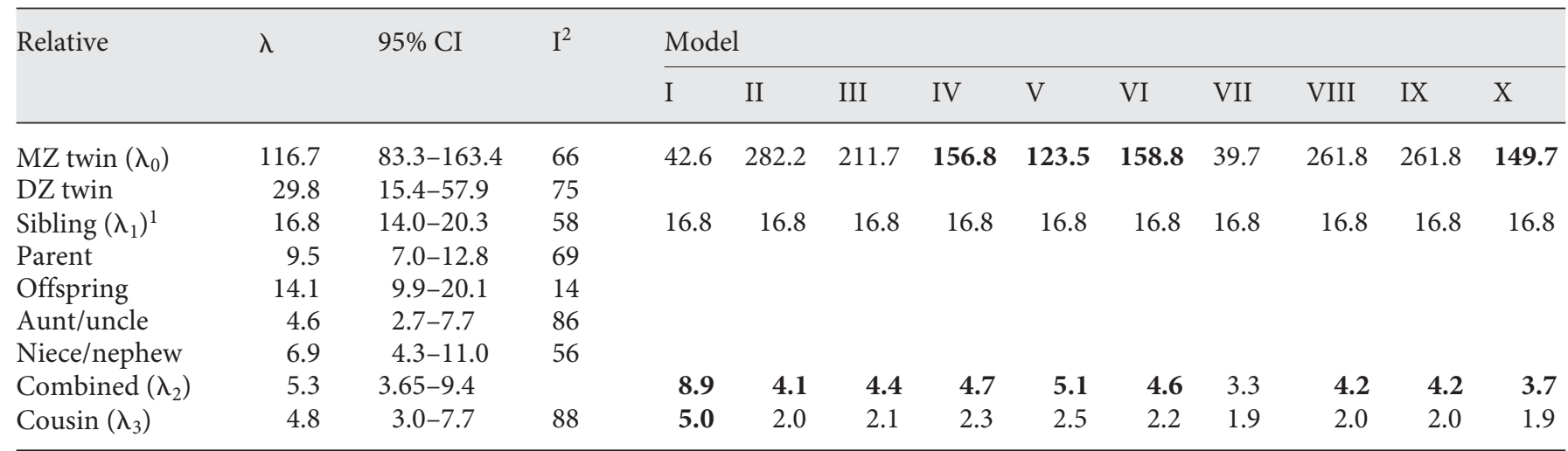

Figures in bold indicate values falling within 95\% CI of observed figures for $\lambda$.

Models (as per Risch 1990) [18]: I = Single locus (recessive); II = infinite loci, small effect; III $=\lambda \_10=2.0+$ infinite; IV $=\lambda \_10=$ $3.0+$ infinite $\mathrm{V}=\lambda \_1 \mathrm{o}=4.0+$ infinite $\mathrm{VI}=\lambda \_10=\lambda \_2 \mathrm{o}=2.0+$ infinite $\mathrm{VII}=\lambda \_1 \mathrm{o}=\lambda \_2 \mathrm{o}=\lambda \_3 \mathrm{o}=2.0+$ infinite $; \mathrm{VIII}=\lambda \_10=$ $1.3+$ infinite; $I X=\lambda \_10=1.3 \lambda \_20=1.019+$ infinite $\bar{X}=\lambda \_10=\lambda \_20=\lambda \_30=1.3+$ infinite.

${ }^{1}$ Models constrained to match the estimated $\lambda_{S}$.

When individual twin studies are analysed and heritability is plotted against latitude, a clear pattern of decreasing heritability with decreasing latitude is seen (fig. 5a; online suppl. table 9). The relevant population prevalence figures are also seen to decline with decreasing latitude (fig. 5b).

\section{Discussion}

We have conducted a meta-analysis of available recurrence risk data for MS. This analysis provides accurate recurrence risk data for a wide range of relative groups with narrow confidence limits, which will be of value 

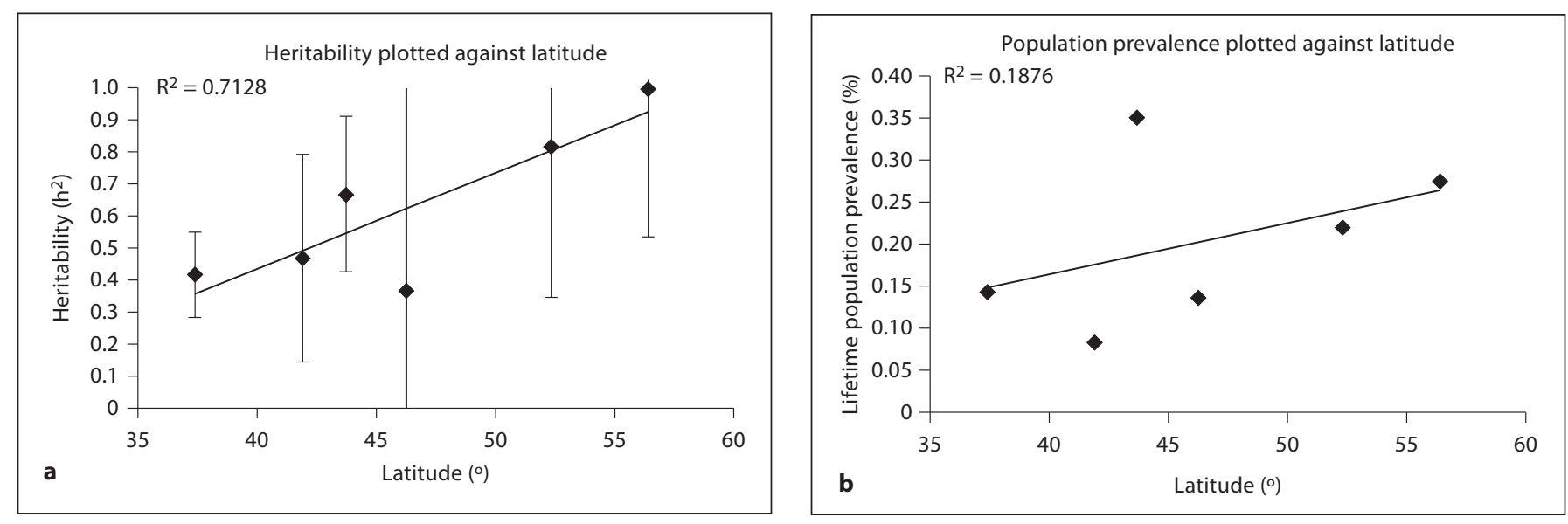

Fig. 5. Plots of heritability (twin data; a) and relevant lifetime population prevalence (b) against latitude.

when counselling people with MS and their families. The present data indicate that there is little difference in genetic risk (as measured by $\lambda$ ) across latitude and that the genetic risk in these populations of predominantly European ancestry is relatively constant. It is therefore entirely appropriate to meta-analyse estimates for $\lambda$. This finding argues against any significant gene-environment interaction acting at the population level with regard to latitude. However, this does not discount the possibility of individual gene-environment interactions. It should be noted that due to the variability and temporal separation of some prevalence figures from the family studies the accuracy of individual $\lambda$ values must be viewed with caution. However, the meta-analysed figure does come with narrow confidence limits, and in the absence of any hidden systematic bias it is likely that these random variations will be negated within the combined result. The funnel plots of $\lambda$ values do not suggest any consistent bias (online suppl. fig. 1).

The finding of a higher risk in siblings when compared with both parents and offspring, and also in half-siblings compared with aunts/uncles and nieces/nephews, suggests that there is a temporal, within-family environmental factor (e.g. epidemic infection). The fact that the ratio of $\lambda_{M}$ is more than twice the $\lambda_{D}$ makes a single locus genetic model very unlikely [18]. The overall estimate for $\lambda_{S}$ was 16.8 , which is towards the lower end of previously quoted estimates [69]. Our overall estimate of genetic heritability in MS was $54 \%$.

The segregation analysis is consistent with the available genomewide association screening data for MS indicating that there is a single locus of moderate effect
[HLA-DRB1 odds ratio $(\mathrm{OR})=3.2$ for $H L A-D R B 1^{*} 15: 01$ allele, allele-specific $\lambda_{S} \approx 1.37$ ] with 56 other loci of modest effect identified thus far (OR 1.1-1.3, locus-specific $\lambda_{S}$ 1.001-1.02). The patterns of familial aggregation seen do not discount the possibility of a second major locus of $\lambda_{\mathrm{S}} \approx 4.0$. Indeed, such a locus would go some way to explaining the unexpectedly high risk seen in cousins. However, the failure of well-powered genetic studies to detect such a locus makes the existence of such a gene in MS unlikely [16].

We have estimated the overall contribution of the known MS loci to the genetic risk of MS to be $18-24 \%$. Thus, there are probably many more genetic associations still to be discovered in MS (for example $\sim 1,500$ variants with a frequency of 0.2 each conferring a relative risk of 1.1 are required to explain the remaining $\lambda_{S}$ ). This calculation ignores the contributions of recessive alleles, shared environmental effects and gene-gene interactions. However, to date, there is no strong evidence of gene-gene interaction in MS susceptibility [16]. A recent analysis of genomewide association data has estimated the number of MS-associated loci to be in the order of 350 [70].

We have demonstrated that for all relatives in the adult age range there is consistent evidence for a latitudinal gradient in the recurrence risk. This relationship is directly proportional to the population risk at these latitudes. This finding provides strong evidence for a true latitudinal gradient in MS prevalence, as these withinfamily studies are less prone to bias from population models of health care due to the high baseline level of suspicion, and the denominator can be more accurately ascertained. The absence of a latitudinal gradient in recur- 
rence risks to younger generations (offspring and nieces/ nephews) suggests that the emergence of disease in these younger groups is more likely to be genetically determined and is less dependent upon environmental risks. There is some evidence for this from genetic studies of HLA which have demonstrated an association between younger age at onset and the $H L A D R B 1^{*} 15: 01$ allele [71]. The obvious candidate for the latitudinally dependent risk factor is relative vitamin $\mathrm{D}$ deficiency $[72,73]$. Two of the loci identified as being associated with susceptibility to MS contain genes involved in vitamin D metabolism (CYP27B1 and CYP24A1) [13, 16], and vitamin D is known to interact with the promoter sequences of a number of MS-associated genes [74].

The variation in recurrence risks for twins has been noted previously [44], and some authors have concluded that this variability makes it impossible to combine twin study data [75]. This variation is readily explained by the variation in heritability with latitude through the effect of population prevalence [76].

The fact that $\mathrm{DZ}$ twin rates are higher than for siblings also suggests a temporal environmental risk factor or potentially an intrauterine effect. A relationship between risk of MS and month of birth has been noted [77], but it is unlikely that this is of sufficient scale $(\mathrm{OR} \approx 1.2)$ to explain the observed difference. Concurrent exposure to infection is a more likely explanation. The final anomaly which requires explanation is the relatively high recurrence risk for cousins. This rate is higher than can be explained by any of the likely genetic models. It has been suggested that this may be the result of a systematic bias in reporting of cases through the female line within fam- ilies or may represent a true excess of female-to-female transmission [78]. However, there is little evidence for this with more closely related family members [64], and cousins are the group most likely to suffer from overreporting of affected cases and underreporting of the total number of cousins. There was evidence for the latter in three of the studies used in this meta-analysis.

In summary, the available recurrence risk data for MS are consistent with a polygenic model of inheritance involving one locus of moderate effect and many more of modest effect with perhaps one fifth to one quarter of the heritability being accounted for by the known loci. Genetic contributions to susceptibility appear to be stable across latitudes and in differing ancestral groups. Risks to relatives rise proportionately with increasing population prevalence as seen at higher latitudes. Thus, caution should be applied when using these overall figures at latitudinal extremes where local data may be more appropriate. The possibility that genetic factors may predominate over environmental factors in earlier-onset disease is suggested by the finding of a latitudinal gradient effect on recurrence risks in older relatives only.

\section{Acknowledgements}

We thank IMSGC and WTCCC2 for access to the data relating to the MS-associated single nucleotide polymorphisms.

\section{Disclosure Statement}

None.

\section{References}

1 Compston A, Coles A: Multiple sclerosis. Lancet 2008;372:1502-1517.

2 Hawkes CH: Smoking is a risk factor for multiple sclerosis: a metanalysis. Mult Scler 2007;13:610-615.

>3 Handel AE, Williamson AJ, Disanto G, Handunnetthi L, Giovannoni G, Ramagopalan SV: An updated meta-analysis of risk of multiple sclerosis following infectious mononucleosis. PLoS One 2010;5:e12496.

4 Islam T, Gauderman WJ, Cozen W, Mack TM: Childhood sun exposure influences risk of multiple sclerosis in monozygotic twins. Neurology 2007;69:381-388.

5 Munger KL, Zhang SM, O’Reilly E, Hernan MA, Olek MJ, Willett WC, Ascherio A: Vitamin D intake and incidence of multiple sclerosis. Neurology 2004;62:60-65.
6 Sadovnick AD, Baird PA: The familial nature of multiple sclerosis: age-corrected empiric recurrence risks for children and siblings of patients. Neurology 1988;38:990-991.

7 Ebers GC, Bulman DE, Sadovnick AD, Paty DW, Warren S, Hader W, Murray TJ, Seland TP, Duquette P, Grey T, et al: A populationbased study of multiple sclerosis in twins. N Engl J Med 1986;315:1638-1642.

8 Ebers GC, Sadovnick AD, Risch NJ: A genetic basis for familial aggregation in multiple sclerosis. Canadian Collaborative Study Group. Nature 1995;377:150-151.

-9 Sadovnick AD, Ebers GC, Dyment DA, Risch NJ: Evidence for genetic basis of multiple sclerosis. The Canadian Collaborative Study Group. Lancet 1996;347:1728-1730.
10 Robertson NP, O’Riordanm JI, Chataway J, Kingsley DP, Miller DH, Clayton D, Compston DA: Offspring recurrence rates and clinical characteristics of conjugal multiple sclerosis. Lancet 1997;349:1587-1590.

11 Jersild C, Dupont B, Fog T, Platz PJ, Svejgaard A: Histocompatibility determinants in multiple sclerosis. Transplant Rev 1975; 22:148-163.

12 GAMES, Transatlantic Multiple Sclerosis Genetics Cooperative: A meta-analysis of whole genome linkage screens in multiple sclerosis. J Neuroimmunol 2003;143:39-46.

13 Australia and New Zealand Multiple Sclerosis Genetics Consortium (ANZgene): Genomewide association study identifies new multiple sclerosis susceptibility loci on chromosomes 12 and 20. Nat Genet 2009;41:824-828. 
14 De Jager PL, Jia X, Wang J, de Bakker PI, Ottoboni L, Aggarwal NT, Piccio L, Raychaudhuri S, Tran D, Aubin C, Briskin R, Romano S, Baranzini SE, McCauley JL, Pericak-Vance MA, Haines JL, Gibson RA, Naeglin Y, Uitdehaag B, Matthews PM, Kappos L, Polman C, McArdle WL, Strachan DP, Evans D, Cross AH, Daly MJ, Compston A, Sawcer SJ, Weiner HL, Hauser SL, Hafler DA, Oksenberg JR: Meta-analysis of genome scans and replication identify CD6, IRF8 and TNFRSF1A as new multiple sclerosis susceptibility loci. Nat Genet 2009;41:776-782.

- 15 Hafler DA, Compston A, Sawcer S, Lander ES, Daly MJ, De Jager PL, de Bakker PI, Gabriel SB, Mirel DB, Ivinson AJ, PericakVance MA, Gregory SG, Rioux JD, McCauley JL, Haines JL, Barcellos LF, Cree B, Oksenberg JR, Hauser SL: Risk alleles for multiple sclerosis identified by a genomewide study. N Engl J Med 2007;357:851-862.

16 Sawcer S, Hellenthal G, Pirinen M, Spencer CC, Patsopoulos NA, Moutsianas L, Dilthey A, Su Z, Freeman C, Hunt SE, Edkins S, Gray E, Booth DR, Potter SC, Goris A, Band G, Oturai AB, Strange A, Saarela J, Bellenguez C, Fontaine B, Gillman M, Hemmer B, Gwilliam R, Zipp F, Jayakumar A, Martin R, Leslie S, Hawkins S, Giannoulatou E, D’Alfonso S, Blackburn H, Boneschi FM, Liddle J, Harbo HF, Perez ML, Spurkland A, Waller MJ, Mycko MP, Ricketts M, Comabella M, Hammond N, Kockum I, McCann OT, Ban M, Whittaker $\mathrm{P}$, Kemppinen A, Weston $\mathrm{P}$, Hawkins C, Widaa S, Zajicek J, Dronov S, Robertson N, Bumpstead SJ, Barcellos LF, Ravindrarajah R, Abraham R, Alfredsson L, Ardlie K, Aubin C, Baker A, Baker K, Baranzini SE, Bergamaschi L, Bergamaschi R, Bernstein A, Berthele A, Boggild M, Bradfield JP, Brassat D, Broadley SA, Buck D, Butzkueven H, Capra R, Carroll WM, Cavalla P, Celius EG, Cepok S, Chiavacci R, Clerget-Darpoux F, Clysters K, Comi G, Cossburn M, Cournu-Rebeix I, Cox MB, Cozen W, Cree BA, Cross AH, Cusi D, Daly MJ, Davis E, de Bakker PI, Debouverie M, D'Hooghe MB, Dixon K, Dobosi R, Dubois B, Ellinghaus D, Elovaara I, Esposito F, Fontenille C, Foote S, Franke A, Galimberti D, Ghezzi A, Glessner J, Gomez R, Gout O, Graham C, Grant SF, Guerini FR, Hakonarson H, Hall P, Hamsten A, Hartung HP, Heard RN, Heath S, Hobart J, Hoshi M, Infante-Duarte C, Ingram G, Ingram W, Islam T, Jagodic M, Kabesch $M$, Kermode AG, Kilpatrick TJ, Kim C, Klopp N, Koivisto K, Larsson M, Lathrop M, Lechner-Scott JS, Leone MA, Leppa V, Liljedahl U, Bomfim IL, Lincoln RR, Link J, Liu J, Lorentzen AR, Lupoli S, Macciardi F, Mack T, Marriott M, Martinelli V, Mason D, McCauley JL, Mentch F, Mero IL, Mihalova T, Montalban X, Mottershead J, Myhr KM, Naldi P, Ollier W, Page A, Palotie A, Pelletier J, Piccio L, Pickersgill T, Piehl F, Pobywajlo S, Quach HL, Ramsay PP, Reunanen M, Reynolds R, Rioux JD, Rodegher M, Roesner S,
Rubio JP, Ruckert IM, Salvetti M, Salvi E, Santaniello A, Schaefer CA, Schreiber S, Schulze C, Scott RJ, Sellebjerg F, Selmaj KW, Sexton D, Shen L, Simms-Acuna B, Skidmore S, Sleiman PM, Smestad C, Sorensen PS, Sondergaard HB, Stankovich J, Strange RC, Sulonen AM, Sundqvist E, Syvanen AC, Taddeo F, Taylor B, Blackwell JM, Tienari P, Bramon E, Tourbah A, Brown MA, Tronczynska E, Casas JP, Tubridy N, Corvin A, Vickery J, Jankowski J, Villoslada P, Markus HS, Wang K, Mathew CG, Wason J, Palmer CN, Wichmann HE, Plomin R, Willoughby E, Rautanen A, Winkelmann J, Wittig M, Trembath RC, Yaouanq J, Viswanathan AC, Zhang H, Wood NW, Zuvich R, Deloukas P, Langford C, Duncanson A, Oksenberg JR, Pericak-Vance MA, Haines JL, Olsson T, Hillert J, Ivinson AJ, De Jager PL, Peltonen L, Stewart GJ, Hafler DA, Hauser SL, McVean G, Donnelly P, Compston A: Genetic risk and a primary role for cell-mediated immune mechanisms in multiple sclerosis. $\mathrm{Na}$ ture 2011;476:214-219.

17 Hemminki K, Lorenzo Bermejo J, Forsti A: The balance between heritable and environmental aetiology of human disease. Nat Rev Genet 2006;7:958-965.

18 Risch N: Linkage strategies for genetically complex traits. I. Multilocus models. Am J Hum Genet 1990;46:222-228.

19 Risch N: Assessing the role of HLA-linked and unlinked determinants of disease. Am J Hum Genet 1987;40:1-14.

20 McDonald WI, Compston A, Edan G, Goodkin D, Hartung HP, Lublin FD, McFarland HF, Paty DW, Polman CH, Reingold SC, Sandberg-Wollheim M, Sibley W, Thompson A, van den Noort S, Weinshenker BY, Wolinsky JS: Recommended diagnostic criteria for multiple sclerosis: guidelines from the International Panel on the diagnosis of multiple sclerosis. Ann Neurol 2001;50:121-127.

21 Polman CH, Reingold SC, Edan G, Filippi M, Hartung HP, Kappos L, Lublin FD, Metz LM, McFarland HF, O'Connor PW, SandbergWollheim M, Thompson AJ, Weinshenker BG, Wolinsky JS: Diagnostic criteria for multiple sclerosis: 2005 revisions to the 'McDonald Criteria'. Ann Neurol 2005;58:840-846.

22 Poser CM, Paty DW, Scheinberg L, McDonald WI, Davis FA, Ebers GC, Johnson KP, Sibley WA, Silberberg DH, Tourtellotte WW: New diagnostic criteria for multiple sclerosis: guidelines for research protocols. Ann Neurol 1983;13:227-231.

23 Schumacher GA, Beebe G, Kibler RF, Kurland LT, Kurtzke JF, Mcdowell F, Nagler B, Sibley WA, Tourtellotte WW, Willmon TL: Problems of experimental trials of therapy in multiple sclerosis; report by the panel on the evaluation of experimental trials of therapy in multiple sclerosis. Ann NY Acad Sci 1965; 122:552-568.

24 Smith SM, Penrose LS: Monozygotic and dizygotic twin diagnosis. Ann Hum Genet 1955;19:273-289.
25 Sutton HE, Clark PJ, Schull WJ: The use of multi-allele genetic characters in the diagnosis of twin zygosity. Am J Hum Genet 1955; $7: 180-188$.

26 Bharucha NE, Bharucha EP, Wadia NH, Singhal BS, Bharucha AE, Bhise AV, Kurtzke JF, Schoenberg BS: Prevalence of multiple sclerosis in the Parsis of Bombay. Neurology 1988;38:727-729.

27 Risch N: Estimating morbidity risks in relatives: the effect of reduced fertility. Behav Genet 1983;13:441-451.

28 Risch N: Estimating morbidity risks with variable age of onset: review of methods and a maximum likelihood approach. Biometrics 1983;39:929-939.

29 Grubbs FE: Sample criteria for testing outlying observations. Ann Math Stat 1950;21: 27-58.

30 Smith C: Concordance in twins: methods and interpretation. Am J Hum Genet 1974; 26:454-466.

- 31 Davie AM: The 'singles' method for segregation analysis under incomplete ascertainment. Ann Hum Genet 1979;42:507512 .

32 RevMan v5.0, Review Manager (RevMan) Copenhagen, Nordic Cochrane Centre, Cochrane Collaboration, 2008.

33 Higgins JP, Thompson SG, Deeks JJ, Altman DG: Measuring inconsistency in meta-analyses. BMJ 2003;327:557-560.

34 Sterne JA, Egger M: Funnel plots for detecting bias in meta-analysis: guidelines on choice of axis. J Clin Epidemiol 2001;54: 1046-1055.

35 Risch NJ: Searching for genetic determinants in the new millennium. Nature 2000; 405:847-856.

36 Falconer DS: The inheritance of liability to certain diseases, estimated from the incidence among relatives. Ann Hum Genet 1965;29:51-76.

37 Columbia, Socioeconomic Data and Applications Centre, 2000. http://sedac.ciesin. columbia.edu/gpw/global.jsp.

38 Kumler MP, Goodchild MF: The population centre of Canada - just north of Toronto; in Janelle DG (ed): Geographical Snapshots of North America. New York, Guilford, 1992, pp 275-279.

39 Australian Institute of Health and Welfare, National Heart Foundation of Australia: Heart, Stroke and Vascular Diseases. Australian Facts. Canberra, Australian Institute of Health and Welfare \& National Heart Foundation of Australia, 1999.

40 Carton H, Vlietinck R, Debruyne J, De Keyser J, D'Hooghe MB, Loos R, Medaer R, Truyen L, Yee IM, Sadovnick AD: Risks of multiple sclerosis in relatives of patients in Flanders, Belgium. J Neurol Neurosurg Psychiatry 1997;62:329-333.

41 Multiple sclerosis in 54 twinships: concordance rate is independent of zygosity. French Research Group on Multiple Sclerosis. Ann Neurol 1992;32:724-727. 
-42 Grasso MG, Frontali M, Bernardi S, Pantano P, Fieschi C: Multifactorial inheritance and recurrence risks of multiple sclerosis in Italian patients. Neuroepidemiology 1989;8: 300-307.

-43 Hansen T, Skytthe A, Stenager E, Petersen HC, Bronnum-Hansen H, Kyvik KO: Concordance for multiple sclerosis in Danish twins: an update of a nationwide study. Mult Scler 2005;11:504-510.

44 Islam T, Gauderman WJ, Cozen W, Hamilton AS, Burnett ME, Mack TM: Differential twin concordance for multiple sclerosis by latitude of birthplace. Ann Neurol 2006;60: 56-64.

-45 Koch-Henriksen N: An epidemiological study of multiple sclerosis. Familial aggregation social determinants, and exogenic factors. Acta Neurol Scand Suppl 1989;124:1123.

-46 Kuusisto H, Kaprio J, Kinnunen E, Luukkaala T, Koskenvuo M, Elovaara I: Concordance and heritability of multiple sclerosis in Finland: study on a nationwide series of twins. Eur J Neurol 2008;15:1106-1110.

-47 Marrosu MG, Lai M, Cocco E, Loi V, Spinicci G, Pischedda MP, Massole S, Marrosu G, Contu P: Genetic factors and the founder effect explain familial MS in Sardinia. Neurology 2002;58:283-288.

$\checkmark 48$ Mumford CJ, Wood NW, Kellar-Wood H, Thorpe JW, Miller DH, Compston DA: The British Isles survey of multiple sclerosis in twins. Neurology 1994;44:11-15.

-49 O'Gorman C, Freeman S, Taylor BV, Butzkueven H, Broadley SA: Familial recurrence risks for multiple sclerosis in Australia. J Neurol Neurosurg Psychiatry 2011;82:13511354.

50 Prokopenko I, Montomoli C, Ferrai R, Musu L, Piras ML, Ticca A, Murgia BS, Bernardinelli L: Risk for relatives of patients with multiple sclerosis in central Sardinia, Italy. Neuroepidemiology 2003;22:290-296.

- 51 Ristori G, Cannoni S, Stazi MA, Vanacore N, Cotichini R, Alfo M, Pugliatti M, Sotgiu S, Solaro C, Bomprezzi R, Di Giovanni S, Figa Talamanca L, Nistico L, Fagnani C, Neale MC, Cascino I, Giorgi G, Battaglia MA, Buttinelli C, Tosi R, Salvetti M: Multiple sclerosis in twins from continental Italy and Sardinia: a nationwide study. Ann Neurol 2006; 59:27-34.

-52 Robertson NP, Fraser M, Deans J, Clayton D, Walker N, Compston DA: Age-adjusted recurrence risks for relatives of patients with multiple sclerosis. Brain 1996;119(Pt 2):449_ 455.
53 Sadovnick AD, Baird PA, Ward RH: Multiple sclerosis: updated risks for relatives. Am J Med Genet 1988;29:533-541.

-54 Sazdovitch V, Verdier-Taillefer MH, Heinzlef O, Alamowitch S, Roullet E: Familial multiple sclerosis: study of 357 consecutive patients (in French). Rev Neurol (Paris) 2000; 156:638-640.

55 Uitdehaag BM, Polman CH, Valk J, Koetsier JC, Lucas CJ: Magnetic resonance imaging studies in multiple sclerosis twins. J Neurol Neurosurg Psychiatry 1989;52:1417-1419.

56 Wikström J, Kinnunen E, Porras J: The agespecific prevalence ratio of familial multiple sclerosis. J Neuroepidemiol 1984;3:74-81.

57 Willer CJ, Dyment DA, Risch NJ, Sadovnick AD, Ebers GC: Twin concordance and sibling recurrence rates in multiple sclerosis. Proc Natl Acad Sci USA 2003;100:1287712882.

58 Simpson S Jr, Pittas F, van der Mei I, Blizzard L, Ponsonby AL, Taylor B: Trends in the epidemiology of multiple sclerosis in Greater Hobart, Tasmania: 1951 to 2009. J Neurol Neurosurg Psychiatry 2011;82:180-187.

59 Tong S: Dizygotic to monozygotic twinning ratio at the Royal Women's Hospital, Melbourne 1947-1997, compared with Australian national twinning incidence. Twin Res 2000;3:12-16.

60 Bulmer MG: The Biology of Twinning in Man. Oxford, Clarendon Press, 1970.

-61 Hoekstra C, Zhao ZZ, Lambalk CB, Willemsen G, Martin NG, Boomsma DI, Montgomery GW: Dizygotic twinning. Hum Reprod Update 2008;14:37-47.

62 Ebers GC, Sadovnick AD, Dyment DA, Yee IM, Willer CJ, Risch N: Parent-of-origin effect in multiple sclerosis: observations in half-siblings. Lancet 2004;363:1773-1774.

63 Dyment DA, Yee IM, Ebers GC, Sadovnick AD: Multiple sclerosis in stepsiblings: recurrence risk and ascertainment. J Neurol Neurosurg Psychiatry 2006;77:258-259.

64 Hupperts R, Broadley S, Mander A, Clayton D, Compston DA, Robertson NP: Patterns of disease in concordant parent-child pairs with multiple sclerosis. Neurology 2001;57: 290-295.

65 Sadovnick AD, Yee IM, Ebers GC, Risch NJ: Effect of age at onset and parental disease status on sibling risks for MS. Neurology 1998;50:719-723.

66 Ebers GC, Yee IM, Sadovnick AD, Duquette P: Conjugal multiple sclerosis: populationbased prevalence and recurrence risks in offspring. Canadian Collaborative Study Group. Ann Neurol 2000;48:927-931.

67 Maghzi AH, Etemadifar M, Shaygannejad V, Saadatnia M, Salehi M, Hassanzadeh A: Conjugal multiple sclerosis in Isfahan, Iran: a population-based study. Mult Scler 2007; 13:673-675.
68 Higgins JPT, Green S (eds): Cochrane Handbook for Systematic Reviews of Interventions Version 5.1.0, updated March 2011. www. cochrane-handbook.org.

- 69 Oksenberg JR, Baranzini SE, Sawcer S, Hauser SL: The genetics of multiple sclerosis: SNPs to pathways to pathogenesis. Nat Rev Genet 2008;9:516-526.

70 Wang JH, Pappas D, De Jager PL, Pelletier D, de Bakker PI, Kappos L, Polman CH, Chibnik LB, Hafler DA, Matthews PM, Hauser SL, Baranzini SE, Oksenberg JR: Modeling the cumulative genetic risk for multiple sclerosis from genome-wide association data. Genome Med 2011;3:3.

71 Hensiek AE, Sawcer SJ, Feakes R, Deans J, Mander A, Akesson E, Roxburgh R, Coraddu F, Smith S, Compston DA: HLA-DR 15 is associated with female sex and younger age at diagnosis in multiple sclerosis. J Neurol Neurosurg Psychiatry 2002;72:184-187.

72 Ascherio A, Munger KL, Simon KC: Vitamin $\mathrm{D}$ and multiple sclerosis. Lancet Neurol 2010;9:599-612.

73 Lucas RM, Ponsonby AL, Dear K, Valery PC, Pender MP, Taylor BV, Kilpatrick TJ, Dwyer T, Coulthard A, Chapman C, van der Mei I, Williams D, McMichael AJ: Sun exposure and vitamin $\mathrm{D}$ are independent risk factors for CNS demyelination. Neurology 2011;76: 540-548.

74 Ramagopalan SV, Heger A, Berlanga AJ, Maugeri NJ, Lincoln MR, Burrell A, Handunnetthi L, Handel AE, Disanto G, Orton SM, Watson CT, Morahan JM, Giovannoni G, Ponting CP, Ebers GC, Knight JC: A ChIP-seq defined genome-wide map of vitamin $\mathrm{D}$ receptor binding: associations with disease and evolution. Genome Res 2010;20: 1352-1360.

75 Hawkes $\mathrm{CH}$, Macgregor AJ: Twin studies and the heritability of MS: a conclusion. Mult Scler 2009;15:661-667.

76 Risch N: The genetic epidemiology of cancer: interpreting family and twin studies and their implications for molecular genetic approaches. Cancer Epidemiol Biomarkers Prev 2001;10:733-741.

77 Willer CJ, Dyment DA, Sadovnick AD, Rothwell PM, Murray TJ, Ebers GC: Timing of birth and risk of multiple sclerosis: population based study. BMJ 2005;330:120.

78 Ramagopalan SV, Dyment DA, Ebers GC: Autoimmune disease in patients with multiple sclerosis and their first-degree relatives: a nationwide cohort study in Denmark. Mult Scler 2008; 14:1288-1289, author reply 12901291. 